岩石鉝物鉝床学会誌

50 巻 5 号, 1963 年

\title{
FERROPARGASITE AND FERROEDENITE IN THE METASOMATIC SYENITES FROM SHODO ISLET, KAGAWA PREFECTURE, JAPAN
}

\author{
Nobuhide Murakami \\ Institute of Earth Science, Faculty of Literature and Science, \\ Yamaguchi University, Yamaguchi \\ TOKINORI MaRUYAMA \\ Osaka Saiseki Co. Ltd., Takarazuka
}

\section{INTRODUCTION}

Several types of peculiar syenitic rocks associated intimately with granitic masses have been found in some parts of southwest Japan. On the basis of field evidences and petrographic characters, Murakami (1956) considered that these syenitic rocks were formed metasomatically by the action of alkali solution originated in deepseated granite magma, but the conditions of their formation and the mutual relations among the constituent minerals have not been clarified. This report is a part of our studies on the above-mentioned problems.

\section{Modes of OCCurrence of Amphiboles}

In Shôdo Islet, syenites containing amphibole and other peculiar minerals are found in the biotite granite of probably upper Cretaceous age. They were first described by Satô (1936). The granite intrudes into the medium-grained hornblende-biotite granite, quartz diorite and biotite gneiss, and is covered by Tertiary andesitic lava and tuff breccia. Many dikes of porphyrite, lamprophyre, granite porphyry and granophyre penetrate the granite in various places of the district. The biotite granite is coarse-grained, leucocratic, and composed mainly of plagioclase (An 12-28), potash feldspar (mostly microcline), quartz and biotite. Its chemical composition is shown in Table 1.

The syenites occur in stock- and dike-like forms and are transitional to the surrounding biotite granite, as shown in Fig. 1. A small vein of aplite in the granite is gradational to a vein of syenite aplite in the syenite. 


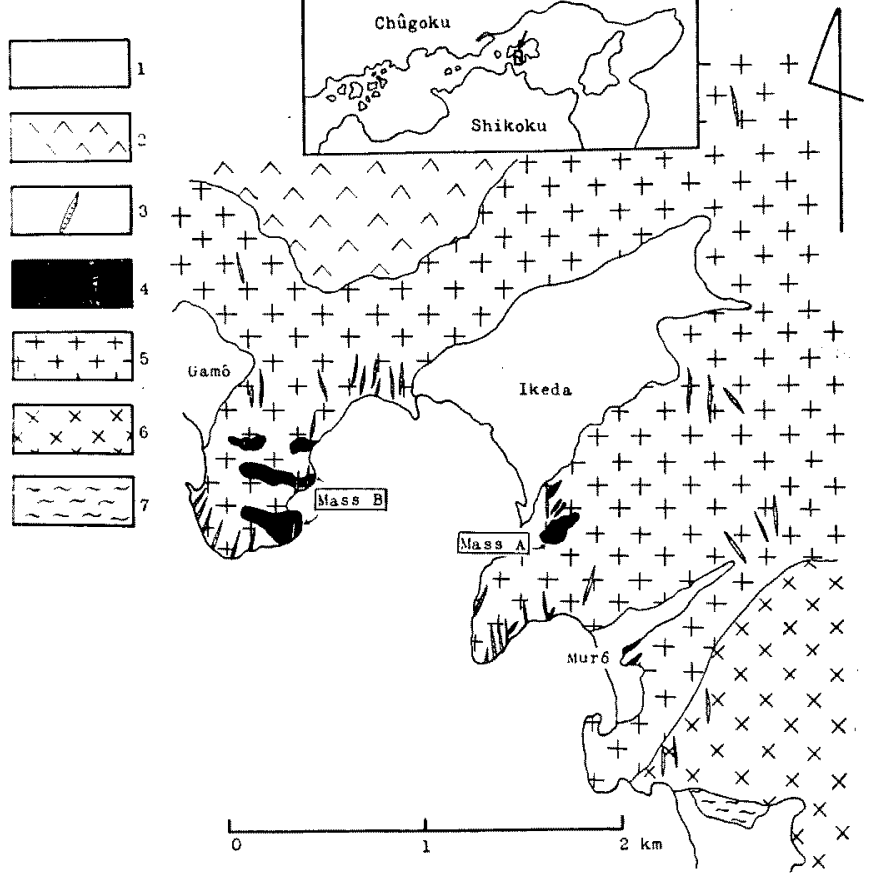

Fig. 1. Geological map of the Ikeda area, Shôdo Islet, Kagawa Prefecture

1: Alluvium, 2: Andesite, andesitic tuff and tuff breccia,

3: Dike rocks, 4 : Syenitic rocks, 5: Biotite granite, 6:

Hornblende-biotite granite, 7 : Biotite gneiss.

The syenties are divided by their constituent mafic minerals into six types as follows:

a) Hedenbergite-quartz syenite

b) Aegirine-augite-quartz syenite

c) Andradite-quartz syenite

d) Ferropargasite-quartz syenite

e) Chlorite-epidote-quartz syenite

f) Epidote-ferroedenite-quartz syenite

The chemical compositions of these syenites are shown in Table 2.

The petrographic features of the ferropargasite-quartz syenite and epidote-

Table 1. Chemical composition of biotite granite (No. 19)

\begin{tabular}{|c|c|}
\hline $\begin{array}{l}\mathrm{SiO}_{2} \\
\mathrm{TiO}_{2} \\
\mathrm{Al}_{2} \mathrm{O}_{3} \\
\mathrm{Fe}_{2} \mathrm{O}_{3} \\
\mathrm{FeO} \\
\mathrm{MnO} \\
\mathrm{MgO} \\
\mathrm{CaO} \\
\mathrm{Na}_{2} \mathrm{O} \\
\mathrm{K}_{2} \mathrm{O} \\
\mathrm{P}_{2} \mathrm{O}_{5} \\
\mathrm{H}_{2} \mathrm{O}(+) \\
\mathrm{H}_{2} \mathrm{O}(-)\end{array}$ & $\begin{array}{r}73.74 \\
0.09 \\
13.41 \\
0.27 \\
0.99 \\
0.05 \\
0.14 \\
1.36 \\
3.91 \\
4.74 \\
0.03 \\
0.56 \\
0.11\end{array}$ \\
\hline Total & 99.40 \\
\hline
\end{tabular}


Table 2. Chemical compositions and oxidation ratios (OR) of syenites

\begin{tabular}{l|r|r|r|r|r|r|r}
\hline \multicolumn{1}{c|}{$\mathrm{No}}$. & \multicolumn{1}{c|}{8} & \multicolumn{1}{c|}{7} & \multicolumn{1}{c|}{56} & \multicolumn{1}{c|}{55} & \multicolumn{1}{c}{52} & \multicolumn{1}{c}{30} & \multicolumn{1}{c}{71} \\
\hline $\mathrm{SiO}_{2}$ & 65.02 & 66.10 & 68.38 & 66.81 & 65.41 & 63.77 & 62.78 \\
$\mathrm{TiO}_{2}$ & 0.21 & 0.23 & 0.38 & 0.18 & 0.15 & 0.23 & 0.61 \\
$\mathrm{Al}_{2} \mathrm{O}_{3}$ & 17.93 & 17.62 & 16.49 & 17.19 & 17.84 & 19.08 & 17.05 \\
$\mathrm{Fe}_{2} \mathrm{O}_{3}$ & 0.51 & 0.93 & 1.28 & 0.68 & 0.48 & 1.30 & 0.72 \\
$\mathrm{FeO}$ & 2.10 & 1.11 & 0.59 & 0.39 & 0.79 & 0.46 & 3.42 \\
$\mathrm{MnO}$ & 0.10 & 0.08 & 0.09 & 0.30 & 0.11 & 0.12 & 0.15 \\
$\mathrm{MgO}$ & 0.64 & 0.57 & 0.71 & 0.34 & 0.60 & 0.85 & 0.80 \\
$\mathrm{CaO}$ & 2.28 & 1.58 & 0.62 & 1.73 & 2.24 & 2.56 & 4.46 \\
$\mathrm{Na}{ }_{2} \mathrm{O}$ & 6.92 & 9.44 & 7.52 & 7.89 & 5.86 & 4.77 & 8.64 \\
$\mathrm{~K}_{2} \mathrm{O}$ & 3.91 & 1.20 & 3.07 & 3.90 & 5.03 & 5.82 & 0.30 \\
$\mathrm{P}_{2} \mathrm{O}_{5}$ & 0.15 & 0.29 & 0.27 & 0.41 & 0.30 & 0.23 & 0.27 \\
$\mathrm{H}_{2} \mathrm{O}(+)$ & 0.34 & 0.17 & 0.26 & 0.16 & 0.64 & 0.82 & 0.80 \\
$\mathrm{H}_{2} \mathrm{O}(-)$ & 0.10 & 0.11 & 0.05 & 0.24 & 0.16 & 0.18 & 0.41 \\
\hline $\mathrm{Total}$ & 100.21 & 99.43 & 100.57 & 100.22 & 99.60 & 100.19 & 100.41 \\
\hline OR* & 17.1 & 44.4 & 66.7 & 61.5 & 28.6 & 72.7 & 17.2 \\
\hline
\end{tabular}

Rock: 8. Hedenbergite-quartz syenite, 7. Aegirine-augite-quartz sy., 56. Aegirine-augite-quartz sy., 55. Andradite-quartz sy., 52. Ferropargasitequartz sy., 30. Chlorite-epidote-quartz sy., 71. Epidote-ferroedenite-quartz sy. (Analyst: T. Maruyama)

ferroedenite-quartz syenite are described below.

Ferropargasite-quartz syenite This rock occurs within Mass A in Fig. 1, and is associated with hedenbergite- and aegirine-augitequartz syenite, although their mutual field relations have not been clarified. It is coarse-grained and composed mainly of plagioclase, potash-feldspar and amphibole, with subordinate quartz, titanite, black iron ore, zircon and apatite.

Plagioclase is devided by their occurrence under the microscope into the following three types:

(i) Large anhedral crystal with or without small granular plagioclase inclusions.

(ii) Large porphyroblast enclosing numerous small granular minerals such as plagioclase, quartz and amphibole. Rarely, it is made up by parallel fine lamellae showing polysynthetic albitetwinning. This peculiar structure resembles the so-called chequer structure (Murakami, 1959).

(iii) Fine- to medium-grained granular crystal which is included in other large minerals. If often occurs as mosaic aggregates.

Usually, the plagioclase shows zonal structure, and the composition (determined optically) is 7-14\% An. $2 \theta_{131}-2 \theta_{1 \overline{3} 1}\left(\mathrm{CuK}_{\alpha}\right)=1.26$. 
Potash feldspar occurs commonly in large interstitial crystals, but often in small granular crystals included in the plagioclase. It is perthitic and often shows cross-hatched twinning in parts. In some sections plagioclase replaces potash feldspar along the marginal boundary or cleavage plane. $2 \mathrm{~V}$ over $\mathrm{X}=72^{\circ}: \Delta$ (Triclinicity) $=$ $0.16-0.24$.

Amphibole occurs in anhedral crystals enclosing poikilitically granular plagioclases. Small granular crystals included in other large minerals are also recognized.

Quartz occurs interstitially or as fine granular crystals.

Epidote-ferroedenite-quartz syenite This rock occurs within Mass B in Fig. 1. The field relations between this rock and other types of syenite have not been found. It is coarse-grained and composed mainly of plagioclase, epidote and amphibole, with subordinate quartz, titanite, chlorite, black iron ore, zircon and apatite. In the transition zone to the granite, small amounts of potash feldspar and biotite occur. This potash feldspar is commonly replaced by plagioclase, and biotite is replaced by amphibole.

Under the microscope, plagioclase occurs commonly in large subhedral to anhedral crystals, although fine granular crystals and fine veinlets are also recognized. Usually, it shows polysynthetic albite-twinning, accompanying untwinned crystals. Zoned crystals are not recognized. The composition is $0-2 \%$ An. $2 \theta_{131}-2 \theta_{1} 1$ ( $\mathrm{Cu}$ $\left.\mathrm{K}_{\alpha}\right)=1.10$.

Epidote occurs in anhedral granular crystals and often as mosaic aggregates or veinlets. It is stably associated with amphibole. $2 \mathrm{~V}$ over $\mathrm{X}=68^{\circ}$.

Amphibole occurs as isolated anhedral crystals and often as small mosaic aggregates. Minutes crystals of black iron ore and titanite are included in this mineral.

\section{Description of Amphiboles}

Ferropargasite and ferroedenite were seperated from their host rocks by means of the magnetic separator and heavy liquid. The color of ferropargasite is black, while that of ferroedenite is dark green.

Chemical compositions Separated specimens of amphiboles were analysed chemically. The compositions, oxidation ratios and the atomic ratios calculated on the basis of $\mathrm{O}+\mathrm{OH}+\mathrm{F}=24$, are shown in Table 3. From this results, it is considered that No. $52 \mathrm{H}$ and No. $71 \mathrm{H}$ have composition close to that of ferropargasite and ferroedenite, 
Table 3. Chemical compositions, oxidation ratios and atomic ratios of amphiboles

\begin{tabular}{|c|c|c|c|c|}
\hline No. & \multicolumn{2}{|l|}{$52 \mathrm{H}$} & \multicolumn{2}{|l|}{$71 \mathrm{H}$} \\
\hline $\begin{array}{l}\mathrm{SiO}_{2} \\
\mathrm{TiO}_{2} \\
\mathrm{Al}_{2} \mathrm{O}_{3} \\
\mathrm{Fe}_{2} \mathrm{O}_{3} \\
\mathrm{FeO} \\
\mathrm{MnO} \\
\mathrm{MgO} \\
\mathrm{CaO} \\
\mathrm{Na}_{2} \mathrm{O} \\
\mathrm{K}_{2} \mathrm{O} \\
\mathrm{H}_{2} \mathrm{O}(+) \\
\mathrm{H}_{2} \mathrm{O}(-) \\
\mathbf{F}\end{array}$ & $\begin{array}{r}41.77 \\
1.18 \\
8.67 \\
6.66 \\
24.22 \\
0.87 \\
2.39 \\
7.29 \\
2.29 \\
0.97 \\
2.65 \\
0.10 \\
0.52\end{array}$ & & $\begin{array}{r}45.70 \\
0.78 \\
5.64 \\
3.49 \\
24.26 \\
1.03 \\
2.88 \\
10.70 \\
1.42 \\
0.68 \\
2.97 \\
0.50 \\
0.11\end{array}$ & \\
\hline $\mathrm{O}$ for $\mathrm{F}$ & 0.25 & & 0.05 & \\
\hline Total & 99.33 & & 100.10 & \\
\hline OR* & 19.8 & & 11.5 & \\
\hline $\begin{array}{l}\mathrm{Si} \\
\mathrm{Al} \\
\mathrm{Al} \\
\mathrm{Ti} \\
\mathrm{Fe}^{\prime \prime \prime} \\
\mathrm{Fe}^{\prime \prime} \\
\mathrm{Mn} \\
\mathrm{Mg} \\
\mathrm{Ca} \\
\mathrm{Na} \\
\mathrm{K} \\
\mathrm{OH} \\
\mathrm{F} \\
\mathrm{O}\end{array}$ & $\left.\begin{array}{r}6.61 \\
1.39 \\
0.22 \\
0.14 \\
0.79 \\
3.19 \\
0.12 \\
0.57 \\
1.34 \\
0.70 \\
0.19 \\
2.45 \\
0.26 \\
21.29\end{array}\right\}$ & $\begin{array}{r}3.88 \\
1.34 \\
0.89 \\
\\
24.00\end{array}$ & $\left.\begin{array}{c}7.07 \\
0.93 \\
0.10 \\
0.09 \\
0.41 \\
3.14 \\
0.13 \\
0.66 \\
1.77 \\
0.43 \\
0.13 \\
3.07 \\
0.05 \\
20.88\end{array}\right\}$ & $\begin{array}{r}3.93 \\
1.77 \\
0.56 \\
24.00\end{array}$ \\
\hline Analyst & T. Ma & yama & N. Mur & kami \\
\hline
\end{tabular}

* Oxidation ratio $\left(2 \mathrm{Fe}_{2} \mathrm{O}_{3} \times 100\right) /\left(2 \mathrm{Fe}_{2} \mathrm{O}_{3}+\mathrm{FeO}\right)$

Table 4. Optical properties of amphiboles

\begin{tabular}{l|c|c}
\hline No. & $52 \mathrm{H}$ & $71 \mathrm{H}$ \\
\hline$\alpha$ & 1.690 & 1.682 \\
$\beta$ & 1.710 & 1.699 \\
$\gamma$ & 1.713 & 1.706 \\
$\gamma-\alpha$ & 0.023 & 0.024 \\
$\mathrm{c} \wedge \mathrm{Z}$ & $22^{\circ}$ & $17^{\circ}$ \\
$2 \mathrm{Vx}$ & $42^{\circ}$ & $66^{\circ}$ \\
$\mathrm{X}$ & pale greenish yellow & pale greenish yellow \\
$\mathrm{Y}$ & green & yellowish green \\
$\mathrm{Z}$ & deep bluish green & bluish green \\
\hline
\end{tabular}


respectively, after the classification of amphiboles by Boyd (1959). It must be noticed that ferropargasite is higher in oxidation ratio and fluorine content but lower in $\mathrm{OH}$-content than ferroedenite.

Optical properties Optical properties of the amphiboles are shown in Table 4. The refractive indices of ferropargasite are higher than those of ferroedenite, while optic axial angle of the former is smaller than the latter.

$X$-ray data X-ray powder data of the amphiboles is shown in Table 5.

\section{Some Genetical Considerations on the AMPHIBOLE-BEARING SYENITES}

The above-described amphibole-bearing syenites are considered to have been derived from the biotite granite by the metasomatic action of alkali solution, from the following evidences:

1) The syenites are gradational to the surrounding granite.

Table 5. X-ray powder data of analysed amphiboles

\begin{tabular}{|c|c|c|c|}
\hline \multicolumn{2}{|c|}{$52 \mathrm{H}$} & \multicolumn{2}{|c|}{$71 \mathrm{H}$} \\
\hline $\mathrm{d}$ & I & $\mathrm{d}$ & I \\
\hline $\begin{array}{l}9.307 \\
9.094 \\
8.435 \\
4.790 \\
4.540 \\
4.239 \\
3.491\end{array}$ & $\begin{array}{r}11 \\
7 \\
100 \\
8 \\
7 \\
7 \\
6\end{array}$ & $\begin{array}{l}9.361 \\
9.132 \\
8.460 \\
4.798 \\
4.559 \\
4.252 \\
3.472\end{array}$ & $\begin{array}{r}10 \\
8 \\
100 \\
8 \\
8 \\
8 \\
8\end{array}$ \\
\hline $\begin{array}{l}3.404 \\
3.298 \\
3.146 \\
2.960 \\
2.828 \\
2.758 \\
2.726\end{array}$ & $\begin{array}{r}7 \\
21 \\
50 \\
6 \\
22 \\
6 \\
11\end{array}$ & $\begin{array}{l}3.408 \\
3.304 \\
3.186 \\
3.148 \\
2.955 \\
2.828 \\
2.725\end{array}$ & $\begin{array}{r}11 \\
10 \\
9 \\
61 \\
8 \\
11 \\
16\end{array}$ \\
\hline $\begin{array}{l}2.613 \\
2.561 \\
2.403 \\
2.360 \\
2.180 \\
2.033 \\
1.909\end{array}$ & $\begin{array}{r}13 \\
6 \\
8 \\
7 \\
8 \\
6 \\
6\end{array}$ & $\begin{array}{l}2.613 \\
2.551 \\
2.398 \\
2.361 \\
2.180 \\
2.033 \\
1.907\end{array}$ & $\begin{array}{r}9 \\
8 \\
8 \\
10 \\
9 \\
8 \\
7\end{array}$ \\
\hline $\begin{array}{l}1.895 \\
1.821 \\
1.663 \\
1.651 \\
1.598\end{array}$ & $\begin{array}{r}8 \\
7 \\
9 \\
6 \\
11\end{array}$ & $\begin{array}{l}1.821 \\
1.663 \\
1.651 \\
1.599\end{array}$ & $\begin{array}{l}7 \\
9 \\
8 \\
8\end{array}$ \\
\hline
\end{tabular}




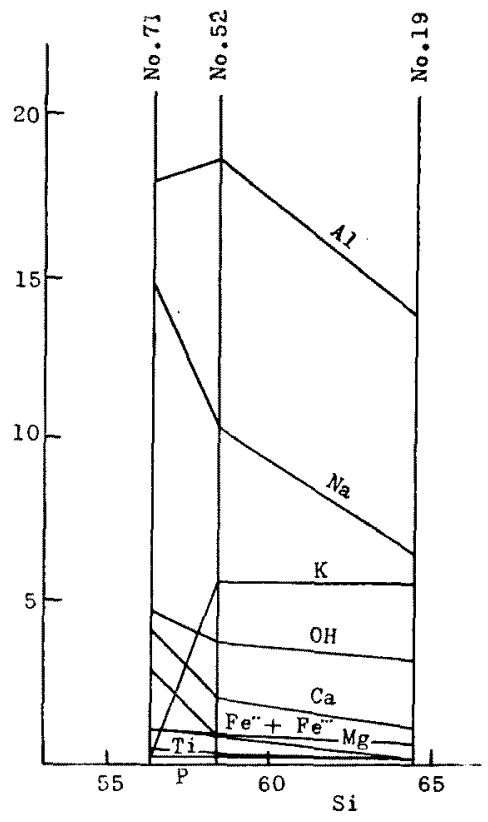

Fig. 2. Variation diagram illustrating the change of chemical composition during syenitization. Numbers correspond to those in Table 1 and 2 .

The texture of the syenites resembles that of the granite.

2) An aplite vein which is transitional to a syenite aplite in the syenite, is found in the granite.

3) Under the microscope, crystalloblastic texture as seen in the mosaic aggregates and poikiloblasts such as plagioclase, amphiboles and epidote, are found, although similar texture is recognized in other types of syenite, too. Potash feldspar replaced by plagioclase and biotite replaced by amphibole, are often found in the syenite of the transition zone.

Fig. 2 shows the relationship between the numbers of cations in standard cell (Barth, 1952) of the amphibole-bearing syenites and those of the surrounding granite. The granite is homogeneous in modal composition in all parts within the granite mass, so that Fig. 2

may be considered to approximately represent the variation of chemical compositions during syenitization of the granite. From this Figure it is inferred that $\mathrm{Al}, \mathrm{Fe}+\mathrm{Fe}, \mathrm{Mg}, \mathrm{Ca}, \mathrm{Na}$ and $\mathrm{OH}$ have been added to the original granite, while $\mathrm{Si}$ and $\mathrm{K}$ have been subtracted from the same rock, although the change of $\mathrm{Fe}+\mathrm{Fe}$ and $\mathrm{K}$ to ferropargasite-quartz syenite from granite is not so conspicuous. Similar metasomatism during syenitization was reported from Canada (Gittins, 1961).

The relationship between the condition of formation of the ferropargasite-quartz syenite and that of ferroedenite-quartz syenite can be inferred from their chemical and mineralogical compositions as follows:

1) The plagioclase in the ferropargasite-quartz syenite is calcic albite to sodic oligoclase, while that in the ferroedenite-quartz 
syenite is sodic albite. Epidote and in some sections chlorite are found as probably stable minerals in the ferroedenite-quartz syenite. On the other hand, the ferropargasite-quartz syenite is intimately associated with pyroxene- and andradite-quartz syenites.

2) The oxidation ratio of the ferropargasite-quartz syenite is higher than that of the ferroedenite-quartz syenite.

3) The fluorine content of the ferropargasite is higher than that of the ferroedenite.

It is considered that the ferropargasite-quartz syenite has been formed under higher temperature and/or lower water vapour pressure, and higher oxygen and fluorine partial pressure than the ferroedenitequartz syenite.

\section{ACKNOWLEDGEMENTS}

We wish to express our thanks to Professor Tôru Tomita of Kyûshu University for his helpful advice. The chemical analyses were performed with assistance of Dr. Noboru Oba of Kagoshima University, and the X-ray data of the amphiboles and feldspars were taken by Professor Asahiko Sugaki of Yamaguchi University, to whom our thanks are also due.

A part of the expense of this study was defrayed by the Department of Education as Research Fund for Natural Sciences.

\section{REFERENCES}

Barth, T.F.W. (1952), Theoretical petrology, John Wiley \& Sons, Inc, New York.

Boyd, F. R. (1959), Hydrothermal investigations of amphiboles. Researches in Geochemistry.

Gittins, J. (1961), Nephelinization in the Haliburton-Bancroft district, Ontario, Canada, Jour. Geol., 69, $291 \sim 308$.

Murakami, N. (1959), Metasomatic syenites occurring in granitic rocks of southwestern Japan, Sci. Rep. Yamaguchi Univ, 10, 73 90.

Satô, G. (1936), Explanatory text of the geological map of Japan, Takamatsu sheet. 1:75000. Imp. Geol. Surv. Japan.

\section{香川県小豆島産交代性閃長岩中の ferropargasite 及び ferroedenite}

$$
\text { 村上允英·丸山時則 }
$$

摘

要

小豆舁池田地域の白至紀黒雲母花岗岩中には小さい岩株・岩脈状をなして種々のタイ 


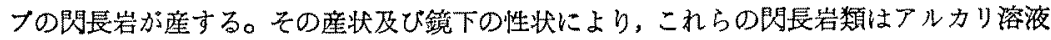
の交代作用により既存の花峛岩から生成されたものと考えられる。門辰岩中には2 㮔の 角閃石が含まれる。その1つは黒色で在曹長石を伴い，他は暗緑色で曹長石・緑れん石 を伴つている。化学組成・光学的性質を就討した結果，前者は Boyd (1959) の分類に よる ferropargasiteに，後者は ferroedeniteにほが相当するすのでるる推定される。 化学組成・共生鉆物・野外の産状等より判断して, ferropargasite は ferroedeniteより も高温或いは低水蒸気圧下・高酸素分圧下・高弗菜分压下に扔いて生成されたと考えら れる。なお，角閉石を含む閃長岩類の化学組成と周辺花崗岩の化学組成との関係上り，周 長岩化に際しては原花崗岩より $\mathrm{Si} \cdot \mathrm{K}$ の除去, Al.total $\mathrm{Fe} \cdot \mathrm{Mg} \cdot \mathrm{Ca} \cdot \mathrm{Na} \cdot \mathrm{OH}$ 等の附加 が行なわれたとの結論に達した。 